\title{
CHANGES IN WASTE PACKAGING MANAGEMENT AND IMPLEMENTATION TO ACHIEVE A CIRCULAR ECONOMY - POLISH CASE STUDY
}

\author{
Joanna Zarębska \\ University of Zielona Góra \\ 9/9 Licealna St., 65-417 Zielona Góra, Poland, j.zarebska@wez.uz.zgora.pl \\ Berenika Lewicka \\ Technische Universität Berlin \\ Straße des 17. Juni 135, 10623 Berlin, Germany, belewiki@campus.tu-berlin.de
}

\begin{abstract}
Currently, within the European Union, the importance of resource efficiency is being highlighted. The issue has been well established within the Europe 2020 strategy and above all within the concept Towards a circular economy: zero waste for Europe'. Using the example of Poland, the authors show changes that have occurred in the management of packaging waste after Poland joined the EU. The data of the Central Statistical Office concerning both municipal and packaging waste allowed to determine changes in waste management and to address them, and the literature on the subject indicates gaps as well as barriers in this area. Building a circular economy (CE) for both packaging goods and waste from packaging in Poland not only requires increasing the involvement of enterprises but also the need for Polish society to be willing to embrace the objectives of the concept of "Zero Waste for Europe" in the European Union.
\end{abstract}

\section{Keywords}

packaging, circular economy, zero waste, waste management

\section{Introduction}

The Polish Ministry of the Environment defines circular economy (CE - Polish: GOZ) as "a concept aiming at rational use of resources and limiting the negative impact of manufactured products on the environment, which similarly to materials and raw materials, should remain in the economy for as long as possible and the generation of waste should be minimized as much as possible" (Ministry of the Environment 2019). A circular economy, to which the concept of 'cradle-to-cradle' (C2C) is closely linked, preserves the added value of products for as long as possible and aims to eliminate waste completely, thereby saving raw materials. It consists in closing the life cycle of products so that the product does not end up in a waste bin or landfill at the end of its life cycle but is reused through recovery, recycling, repair, refurbishment, replacement of parts or complete conversion into another good. This concept also applies to in-production recycling by companies and the so-called "waste exchange" (based on the principle of environmental communication and cooperation between different companies) (Zarębska 2019, p. 31-66).

The implementation of CE measures was initiated with the adoption of many programme documents by the European Community, (e.g. by the European Commission, the Council of the European Union, the European Economic and Social Committee and the Committee of the Regions).

The Treaty on European Union, whose main objectives are to achieve sustainable economic growth, sustainable production and consumption, a high level of protection and improvement of the quality of the environment, sustainable management of natural resources, etc., has been adopted by the European Community. These include:

- Directive 2008/98/EC - achieving the so-called "recycling society" amended Directive (EU) 2018/851, which emphasizes the promotion of the principles of circular economy (CE), strengthening efforts in the field of preparing for re-use and recycling of waste,

- $\operatorname{COM(2011)} 21$ - A resource-efficient Europe - Flagship initiative under the Europe 2020 Strategy,

- $\operatorname{COM(2011)~} 571$ - Roadmap to a Resource Efficient Europe - Improving products and changing consumption patterns, improving production efficiency, transforming waste into resources, supporting research and innovation towards a resource efficient society,

- $\operatorname{COM(2014)} 398$ - Towards a closed-loop economy: A zero-waste programme for Europe. 
The main objective of these documents is to achieve a waste-free economy, in which every commodity used (waste), and in particular packaging, is considered a valuable secondary raw material that needs to be reused for the economic cycle. CE is moving away from a linear model to a closed/circular waste management system. In the case of packaging waste it is considered $100 \%$ recyclable and wholesome recyclable secondary raw materials can be used as well.

Using Poland as the study example, the aim of the article is to show the dynamics of changes that have occurred in the management of packaging waste after Poland's accession to the EU, i.e. after 2004. The developed lists of municipal and packaging waste allow to determine changes in waste management and responses to them. On the basis of the literature review and analysis of the compilations, the authors identified exemplary gaps and barriers in this area. Removal of these barriers may lead to the acceleration of changes in waste management and lead to implementing a so-called "recycling society" in Poland.

1. Legal basis for the pursuit of a CE

Like other Member States, Poland's legislation must be adapted to meet EU requirements. However, in some cases, concessions have been made to EC directives by Polish national regulations. An example of this is the regulation concerning management of municipal and packaging waste. According to the Regulation of the Minister of the Environment regarding annual rates of recovery and recycling of packaging waste from households (Journal of Laws 2018, pos. 2306), Poland is bound by its obligations until 2020:

- up to $35 \%$ reduction of the mass of biodegradable municipal waste transferred to landfills,

- at least a $50 \%$ increase of the level of recycling, preparation for reuse and recovery by other methods of paper, metals, plastics, glass,

- at least $70 \%$ increase of the level of recycling, preparation for reuse and recovery of non-hazardous construction and demolition waste.

Table 1 presents a comparison of Polish and EU legislation as far as the planned percentage recycling rates for packaging waste by 2030 . As shown, the planned percentage recycling rates of packaging waste in the years 2014-2020 (old) / 2018-2020 (new) were changed in the regulations in the direction of reducing the recycling rate, rather than increasing, as in $\operatorname{COM(2014)~397.~The~EU~assumes~the~elimination~of~waste~to~"zero",~and~within~}$ this concept, packaging waste is theoretically the easiest to recover and recycle in its entirety and to achieve the objectives of the Regulation. However, Polish national legislation has clearly slowed down efforts to make changes to achieve the highest recycling rates. This is likely a result of the municipal waste management policy, which is closely linked to lack of financing as well as shortcomings in introducing modern waste treatment technologies, cleaner production technologies, etc.

Despite small changes in the planned percentage recycling rates, the management of municipal and packaging waste in Poland is making dynamic changes. These changes are in line with the EU assumptions and are particularly visible in the multiannual financial statements covering the years from 2004, i.e. after Poland's accession to the EC.

Table 1. Comparison of Polish and EU legislation in terms of planned levels of recycling of packaging wastes. Source: Source: Own research based on a study by Zarębska et al. 2018, p. 59; Journal of Laws 2018, pos. 2306.

\begin{tabular}{|c|c|c|c|c|c|c|c|}
\hline \multirow{4}{*}{$\begin{array}{l}\text { Type of packaging } \\
\text { material }\end{array}$} & \multicolumn{7}{|c|}{ Recycling and preparation level to reuse of packaging waste till end of the year [\%] } \\
\hline & 2014 & 2020 & 2018 & 2020 & 2020 & 2025 & 2030 \\
\hline & \multicolumn{4}{|c|}{ national legislation } & \multirow{2}{*}{\multicolumn{3}{|c|}{$\operatorname{COM}(2014) 397$}} \\
\hline & \multicolumn{2}{|c|}{ old } & \multicolumn{2}{|c|}{ new $2014(2018)^{1)}$} & & & \\
\hline $\begin{array}{ll}\text { Paper } & \text { and } \\
\text { cardboard } & \end{array}$ & 60 & 61 & 30 & $50(24)$ & 85 & 90 & 90 \\
\hline Plastic & 22,5 & 23,5 & 30 & $50(44)$ & 45 & 60 & 60 \\
\hline Glass & 60 & 61 & 30 & $50(56)$ & 70 & 80 & 90 \\
\hline Ferrous metals & 50 & 51 & \multirow[t]{2}{*}{$30^{2)}$} & \multirow{2}{*}{$\begin{array}{l}50^{2)}(34) \\
(56)\end{array}$} & 70 & 80 & 90 \\
\hline Aluminum & 50 & 51 & & & 70 & 80 & 90 \\
\hline Wood & 15 & 16 & - & $-(0)$ & 50 & 65 & 80 \\
\hline Multimaterial $^{3)}$ & 25 & - & 40 & 61 & \multicolumn{3}{|c|}{ By the dominant material } \\
\hline Total & $55-80$ & 56 & - & - & 60 & 70 & 80 \\
\hline
\end{tabular}

1) Levels are calculated together for all of the specified fractions of municipal waste. 2) Metal in general. 3) For multi-material packaging the recycling rate is the same regardless of the dominant material (Art. 25 paragraph 1 of the Act on packaging and packaging waste). 
2. Changes in municipal and packaging waste management

According to Directive (EU) 2018/851 "municipal waste represents approximately 7 to $10 \%$ of all waste generated in the Union. However, it is one of the most complex waste streams and its management mode generally demonstrates the quality of the overall waste management system in a given country.

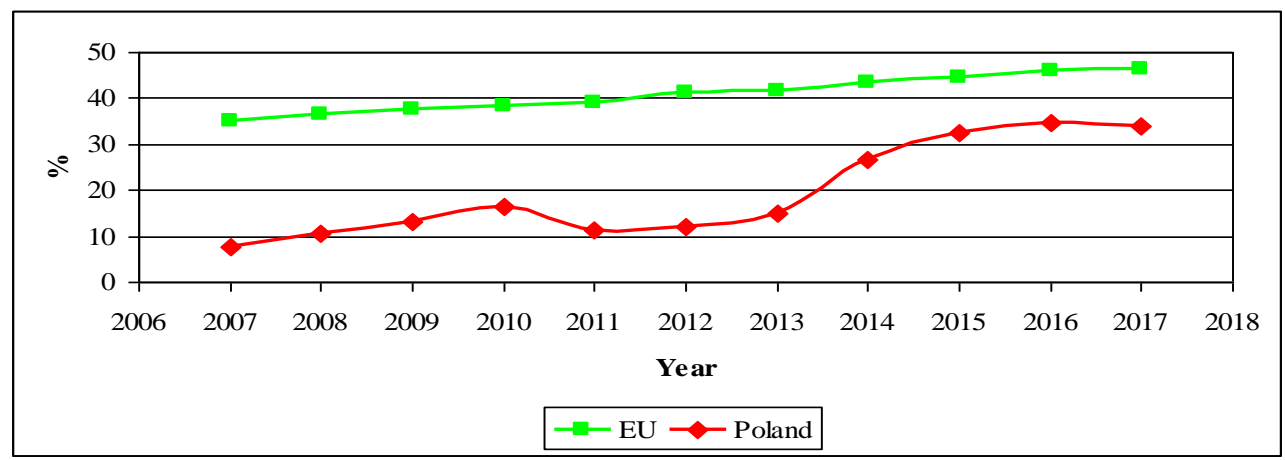

Fig. 1. Level of municipal waste recycling for the period 2007-2017 [\%]. Source: Source: Own research based on the Eurostat 2019 study.

Changes in the management of municipal and packaging waste in Poland are particularly visible when the data for several or more years are compiled. Fig. 1 presents a comparison of the percentage shares of municipal waste recycling between 2007-2017 in Poland to the EU percentages. In the EU, the upward trend in municipal waste recycling has been linear, uniform and stable, while in Poland the growth has been uneven, depending on the year of compilation. Overall, there is a trend for Poland to approach the EU average, but the growth rate is quite slow. Fig. 2 presents the level of municipal waste recycling in 2017 in European countries (Eurostat 2019). Poland is ranked as the 9 th country below the top EU average (28). At that time, its recycling rate was $33.8 \%$ and was lower than countries such as the Czech Republic (34.1\%), Bulgaria (34.6\%), Hungary (35\%), Norway (38.8\%), Finland (40.5\%), France (42.9\%), United Kingdom (43.8\%) and Denmark (46.3\%).

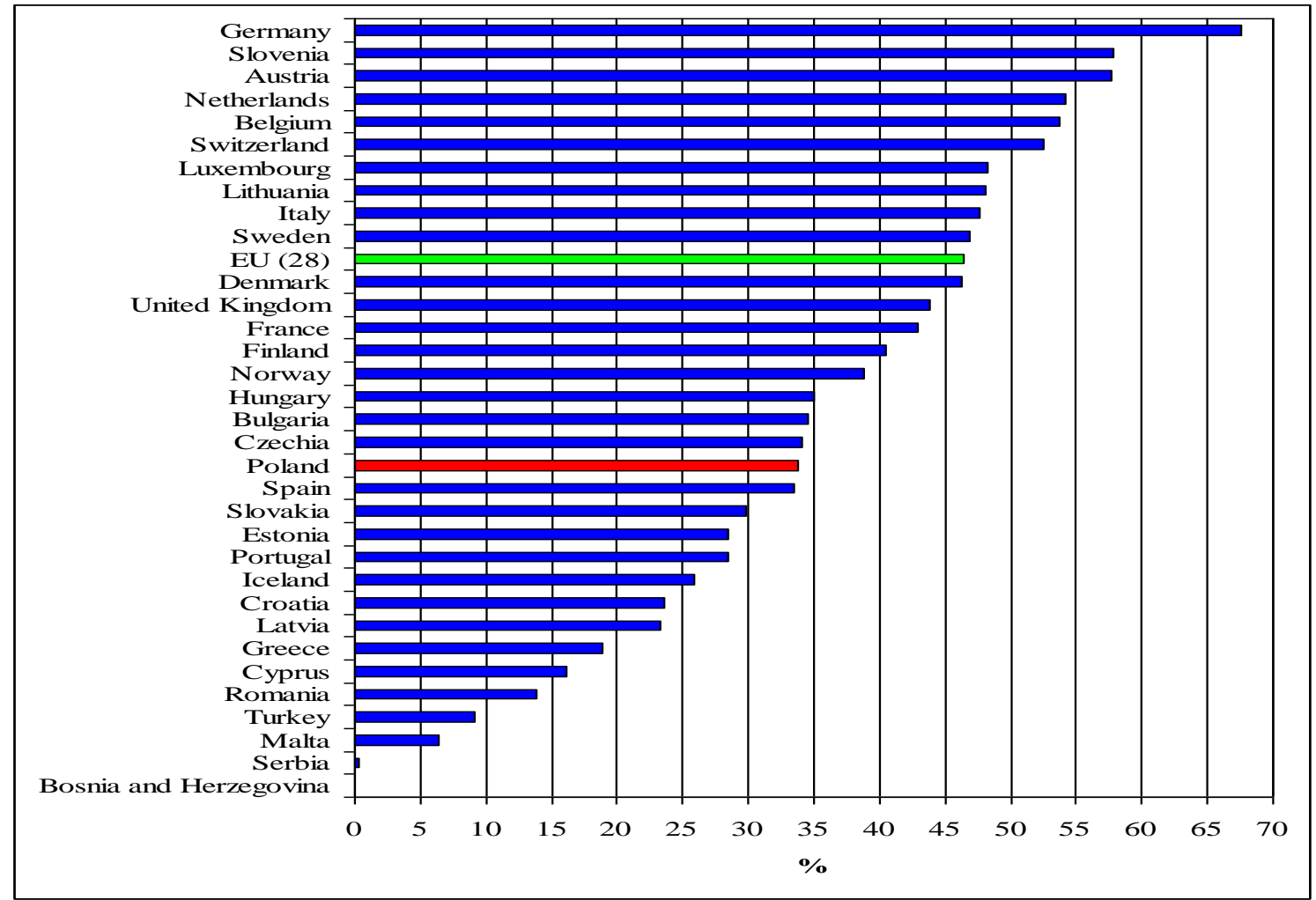

Fig. 2. Level of municipal waste recycling in 2017 by selected EU countries [\%]. Source: Source: Own research based on study based on Eurostat 2019. 
Fig. 3 presents the percentage shares of packaging waste recycling during the years 2007-2016 in Poland in comparison to the EU average. In the EU, the upward trend in packaging waste recycling was linear, similar to that of municipal waste (Fig. 1). In Poland, the level of packaging waste recycling was 58\%, which was not uniform, but approached the EU average of 67.2\% in 2016 (Eurostat 2019).

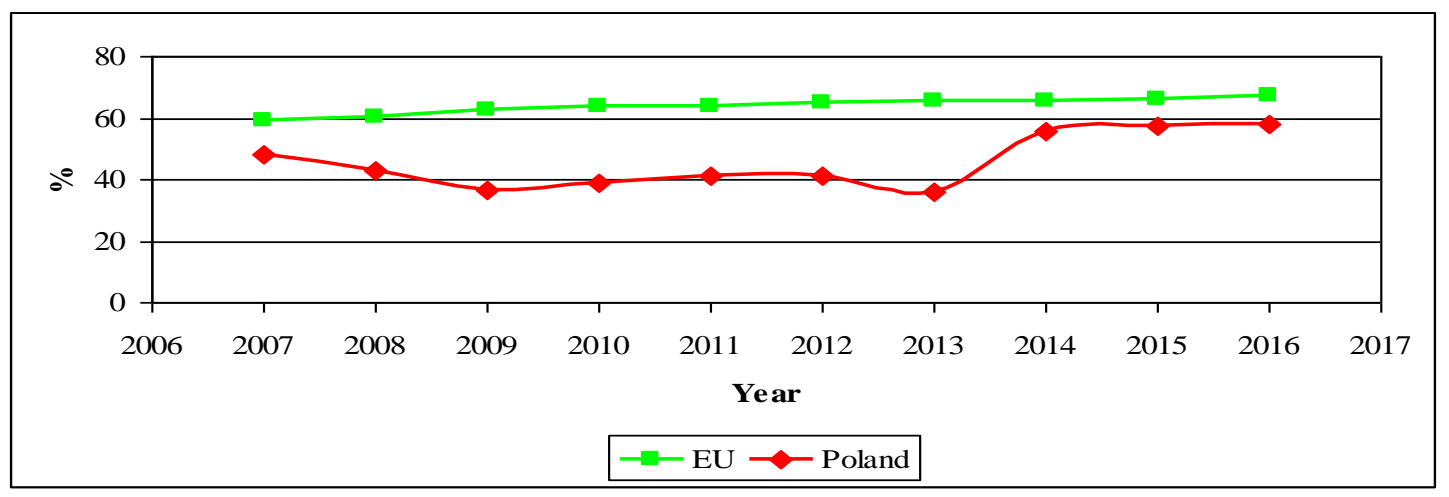

Fig. 3. Level of packaging waste for the period 2007-2017 [\%]. Source: Source: Own research based on the Eurostat 2019 study.

The recycling rate of packaging waste in 2016 in selected European countries is presented in Fig. 4 (Eurostat 2019). In this comparison, Poland rated even worse than in the case of municipal waste, as it was the 15th country below the EU average (28). Its recycling rate of packaging waste in 2016 was 58\%, while the European average was $67.2 \%$. The highest ranked countries recycling rates were: Belgium (81.9\%), Denmark (79\%), Czech Republic (75.3\%), Netherlands (72.6\%) and Germany (70.7\%).

Despite Poland's low position in Figs. 2 and 4 in relation to other European countries, the dynamics of change has been in favour of waste management and clearly indicates Poland's aspiration to implement the CE concept. These changes are particularly visible in the list of masses of collected municipal waste in Poland recovered or disposed of during the years 2004-2016 (Fig. 5). Increasingly more municipal waste is being recycled, composted or incinerated with energy recovery and continually less in landfills.

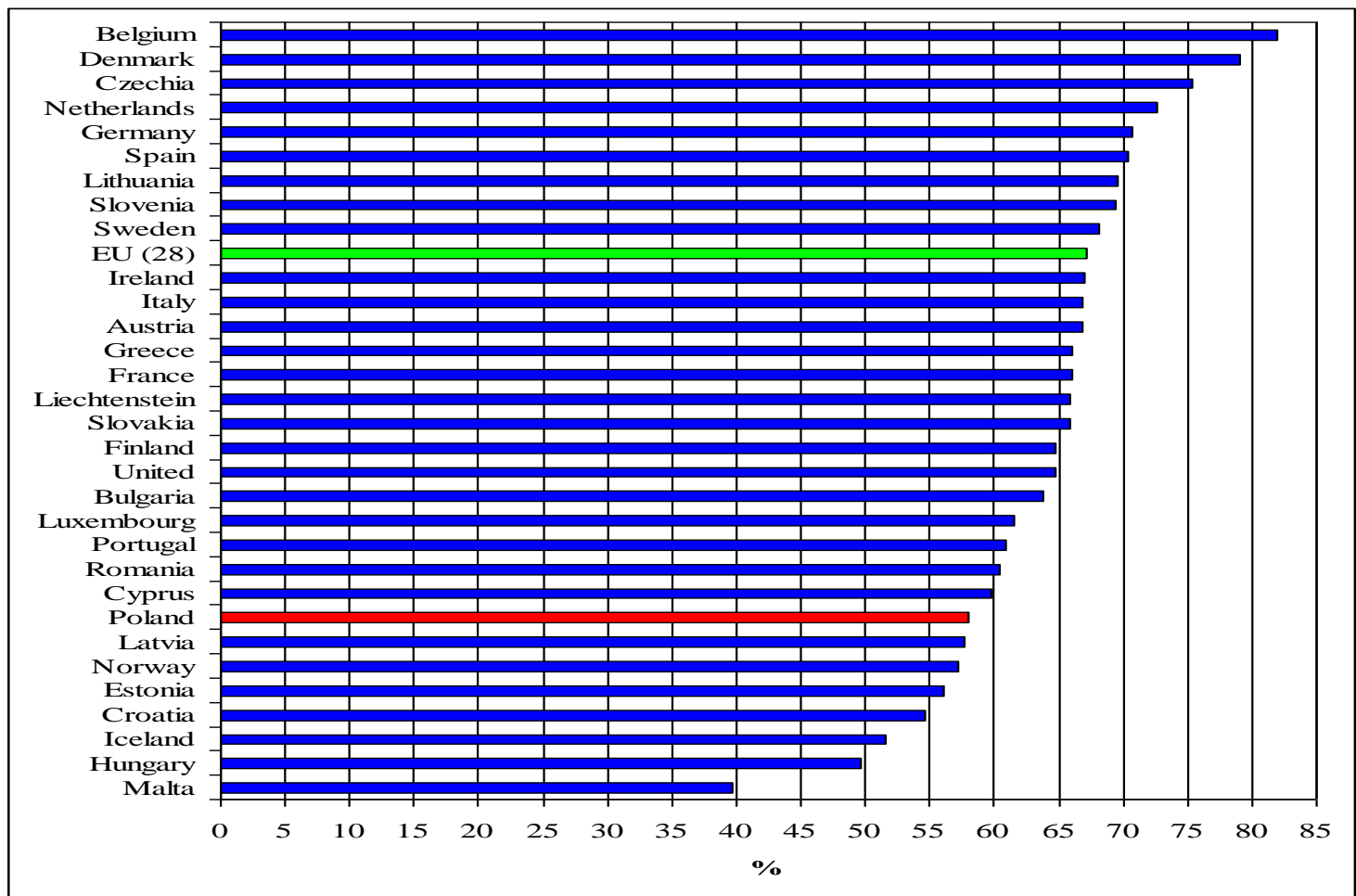

Fig. 4. EU countries packaging waste recycling levels in 2016 [\%]. Source: Source: Own research based on the Eurostat 2019 study 


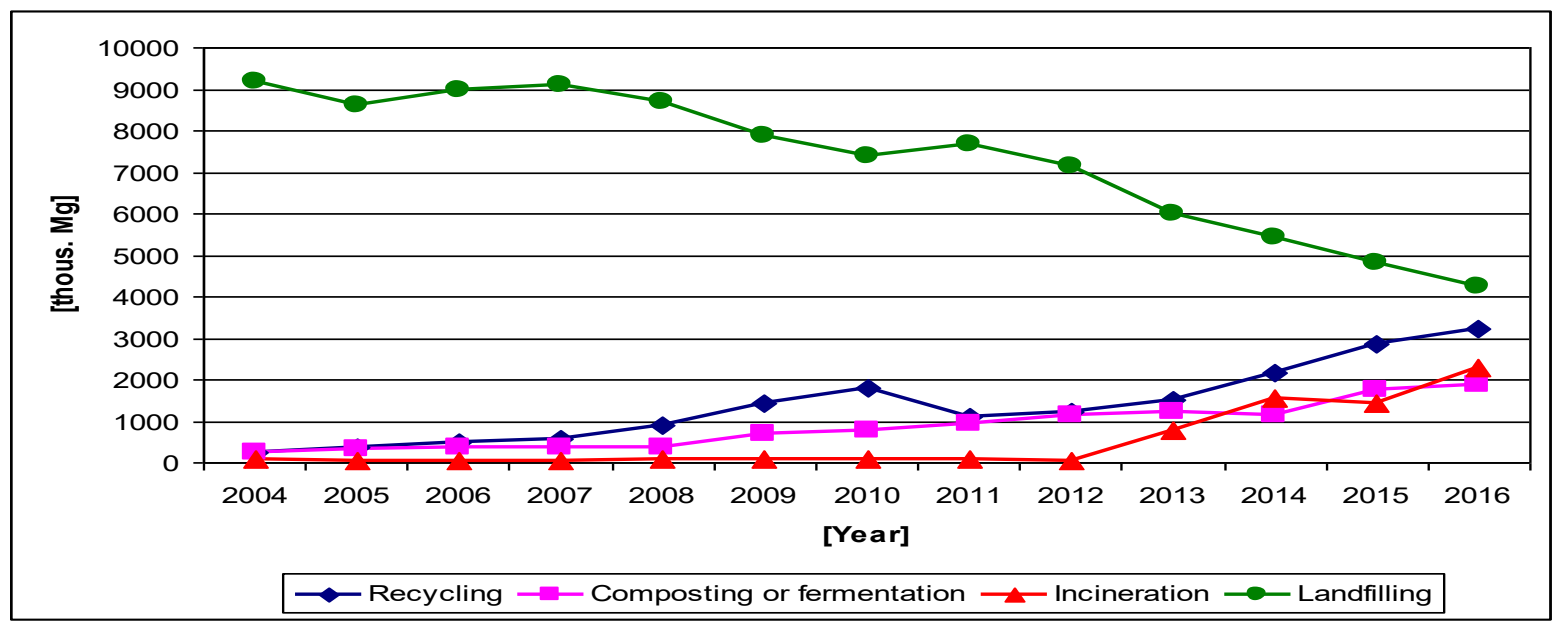

Fig. 5. Comparison of statistical data on the weight of collected municipal waste in Poland subjected to recovery or disposal. Source: [Zarębska et al. 2018, p. 58].

According to the Central Statistical Office (CSO - Polish: GUS) data, Poland has produced less municipal and packaging waste every year than in the other EU countries. In 2016, the average European generated $483 \mathrm{~kg}$ of municipal waste, while the average Pole generated $303 \mathrm{~kg}$. However, it is worrisome that each year Poland has produced more municipal waste (in 2018, on average over $312 \mathrm{~kg}$ per capita; for example, in Białystok - 358 $\mathrm{kg}$, and in Wrocław - $522 \mathrm{~kg}$ ). Poland continues to send much waste to landfills, which is considered by the Polish and EU legislators to be the least desirable way of dealing with waste. Four Polish cities use landfills for almost $25 \%$ of the waste they generate, with the largest number of landfill sites being Łódź (27.6\%), Rzeszów (25.8\%), Kielce $(24.3 \%)$ and Zielona Góra $(23.8 \%)$. This is much considering the fact that by 2035 Poland is expected to reduce the amount of landfill storage to $10 \%$ by 2035 (CSO 2018).

Continually more packaging is being produced and introduced to the market, and thus in turn, more and more packaging waste is being produced. As shown in Fig. 6, more and more packaging waste is also being recycled and recovered.

Research conducted in Poland during the years 2015-2016 by Joanna Zarębska (Zarębska 2019) showed that according to respondents, the reason for the still low level of packaging waste recovery in households and lack of segregation is most often due to:

- lack of containers at the place of residence - $19.9 \%$,

- lack of space at home for containers - $19.1 \%$,

- lack of proper habits in waste segregation - $8.6 \%$,

- lack of time - $7 \%$,

- lack of faith in the proper functioning of the "at source" segregation system - 33\%.

Of the respondents who declared themselves as persons segregating municipal waste, only $70 \%$ stated they segregate waste in all groups (paper, metal, plastic, glass separately). Additionally, $76 \%$ of respondents do not pay attention to labels and markings placed on the packaging, so they probably do not always segregate it correctly. 


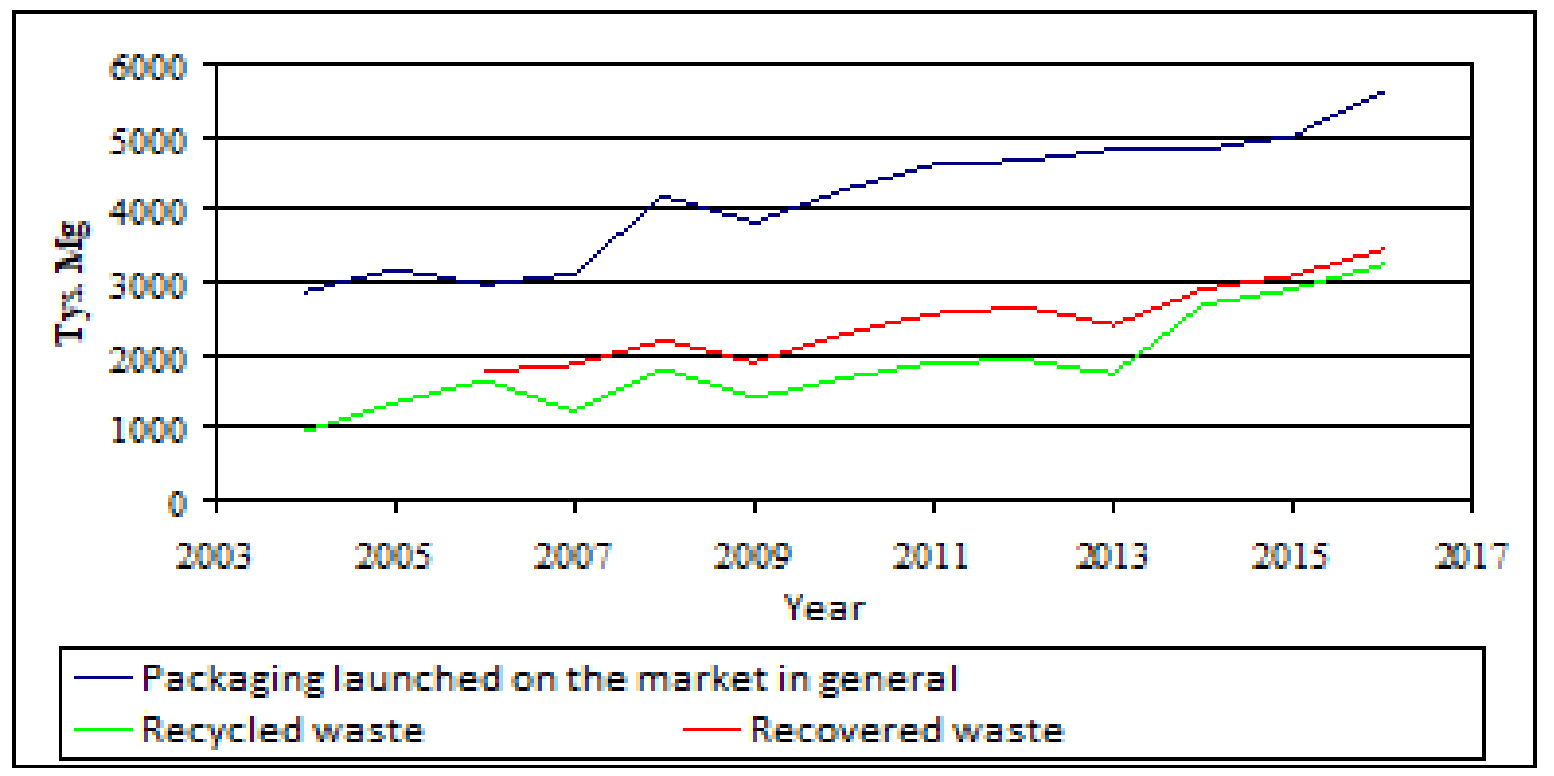

Fig. 6. Packaging launched on the market and achieved levels of recovery and recycling of packaging waste [in thousand Mg]. Source: [Zarębska 2019, p. 43].

Respondents see the possibility of increasing the effectiveness of the selective collection system for packaging waste by education of children, purchase of selected waste by large-area stores (supermarkets) and smaller housing estate stores, media information programmes and social demonstration actions concerning proper waste segregation (Fig. 7).

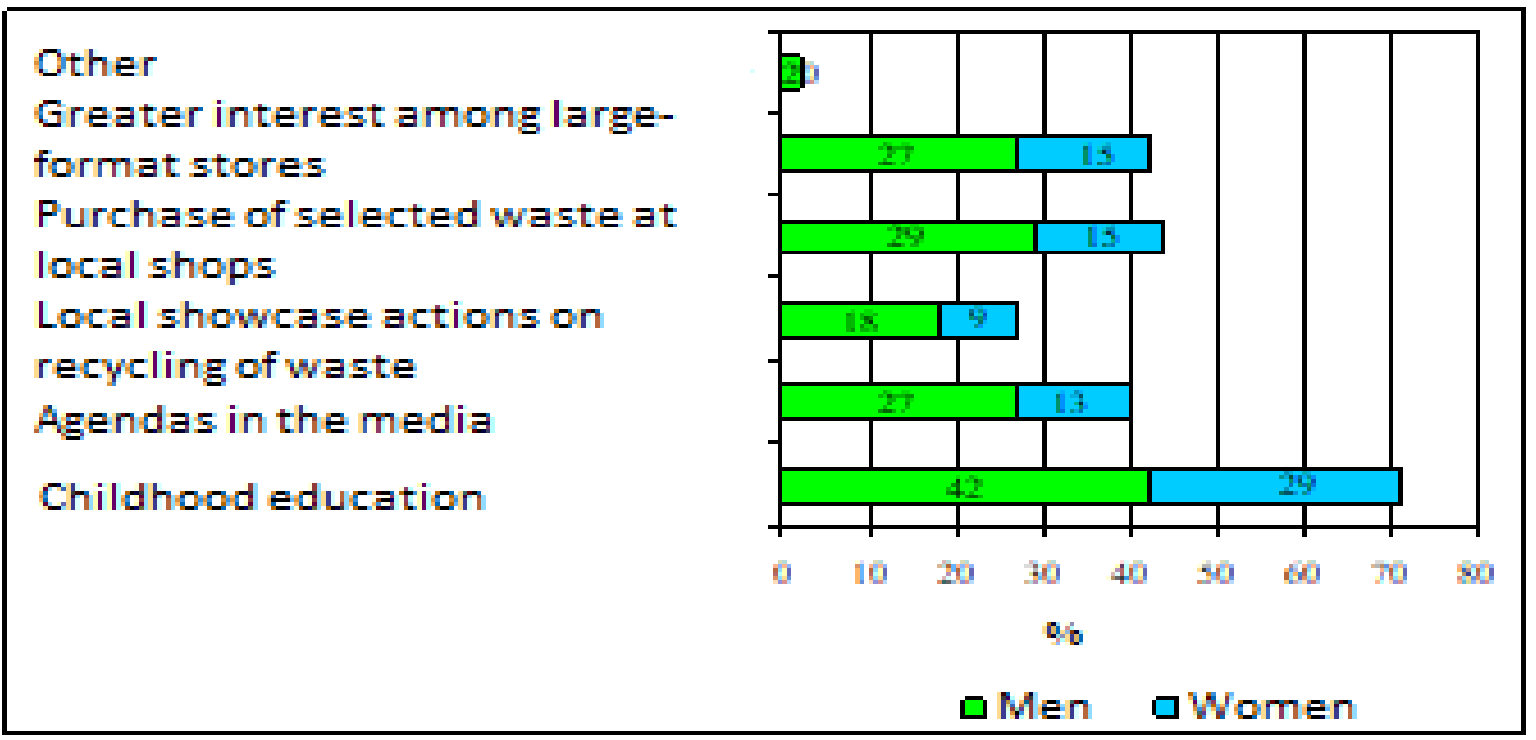

Fig. 7. Proposals to increase the effectiveness of the selective collection system for packaging waste. Source: [Zarębska 2019, p. 265].

The CE concept will not be achieved without the support of a "recycling society", so there is still much room for improvement and catching up to do. Effective waste management can be achieved by increasing the level of segregation of municipal and packaging waste in households, the involvement of citizens and businesses to increase the recovery and recycling of municipal waste, subsidizing the infrastructure of waste management, developing education and consumer awareness and unifying labelling on packaging and containers for waste.

\section{Impact}

Without introducing innovative system solutions, applying modern waste processing technologies and cleaner production methods, by 2025 Poland will not be able to match the European average level of municipal waste 
recycling (above 46\%) and recycling of packaging waste (above 67\%). By 2025, EU Member States will have to achieve a recycling rate of $55 \%$ of municipal waste, $60 \%$ by 2030 and $65 \%$ by 2035 . This level is rather unrealistic to achieve in Poland, but nevertheless, can be achieved through the implementation of innovative measures, as well as increased education of the society and the most appealing option of economic tools. Unfortunately, economic tools are most often associated with increased fees for utilities, which are already high and which arouse widespread social discontent.

To solve the problem of municipal waste management (in particular packaging waste), in September 2019, the Council of Ministers approved the "Roadmap for transformation towards a closed-loop economy" prepared by the Ministry of Entrepreneurship and Technology. The closed-loop economy (CE) is rational, low-emission, innovative and competitive. The Polish GOZ road map is a signpost for the development of this economic system in Poland and indicates specific actions to be taken at all stages of the product life cycle, starting from raw material acquisition, through design, production, consumption, waste collection and management. As mentioned earlier, the implementation of the GOZ concept and the related increase in the recovery and recycling of packaging waste is not possible without a proper organisation process and product innovations. All these activities are aimed at reducing the uncertainty related to the achievement of ecological and economic success, which would be the implementation of GOZ intended to lead to a "recycling society". The involvement of the Polish society in specific activities of the "GOZ Roadmap" is already becoming visible, e.g. the use of biodegradable dishes and paper straws for beverages, reduction of packaging, use of reusable shopping bags, recovery of recyclable materials. However, these activities are not universally applied.

\section{Conclusions}

By studying the analysis of the Polish example in terms of the dynamics of changes in the management of municipal and packaging waste in the context of the $C E$, one can safely emphasize the great achievements made in this field. Positive changes can be seen in Poland's national summaries over several years (Figs. 1, 3, 5), whereas in the summaries, which compare European countries and Poland (Figs. 2 and 4), there is a clear difference when compared to the leading countries. As continually more waste is produced by Europeans, it is highly important for the aim of the CE to intensify efforts to achieve high levels of recovery and recycling of municipal waste. This trend is particularly desirable in the management of packaging waste, which in practice should not be deposited in landfills or dumped in water.

Appropriate environmental communication between organizations of the entire waste management system (of which the public is an important link) may be helpful in establishing cooperation in the field of waste minimization (according to the concept of the "zero waste programme for Europe") and resource efficiency.

\section{Conflict of interests}

There are no conflicts to declare.

\section{Acknowledgments}

This research has not been supported by any external funding.

\section{References}

[1] Directive (EU) 2018/851 of the European Parliament and of the Council of 30 May 2018 amending Directive 2008/98/EC on waste, 2018, OJ L 150, 14.6.2018, p. 109-140. Brussels.

[2] Central Statistical Office (CSO) 2018. Environment 2018, (in Polish), Warsaw.

[3] $\operatorname{COM(2011)~} 21$ final, 2011, A resource-efficient Europe - Flagship initiative under the Europe 2020 Strategy Com. from the Commission to the EP, the Council, the European Economic and Social Committee and the Committee of the Regions, European Commission, Brussels.

[4] $\operatorname{COM(2011)~} 571$ final, 2011, Roadmap to a Resource Efficient Europe, Com. from the Commission to the European Parliament, the Council, the European Economic and Social Committee and the Committee of the Regions, European Commission, Brussels.

[5] $\operatorname{COM(2014)~} 398$ final, 2014, Towards a circular economy: A zero waste programme for Europe, Com. from the Commission to the EP, the Council, the European Economic and Social Committee and the Committee of the Regions, European Commission, Brussels.

[6] Consolidated Version of the Treaty on European Union, 2012, OJ of the EU C 326/15, Available at: https://eur-lex.europa.eu/resource.html?uri=cellar\%3A2bf140bf-a3f8-4ab2-b506-

fd71826e6da6.0023.02/DOC_1\&format=PDF [Accessed: 10 Apr 2019]

[7] Eurostat 2019, Official Website. Available at: http://ec.europa.eu/eurostat/statisticsexplained/index.php/Municipal_waste_statistics [Accessed: 10 Apr 2019]. 
[8] Ministerstwo Środowiska 2019, Official Website. Available at: https://www.gov.pl/web/srodowisko/goz [Accessed: 12 July 2019].

[9] Rozporządzenia Ministra Środowiska w sprawie rocznych poziomów odzysku i recyklingu odpadów opakowaniowych pochodzących z gospodarstw domowych (Journal of Laws 2018, pos. 2306), (in Polish), Warsaw.

[10] Zarębska J., 2019: Packaging waste management in the context of a circular economy - the essence, tools, environmental communication. University of Zielona Góra (in Polish), ISBN 978-83-7842-379-9.

[11] Zarębska J., Żabińska I., Cierna H., Sujova E., 2018: Assessment of the changes in the economy of municipal waste in Poland after 2004, [in:] Human Safety in Work Environment, Operating Machinery and Equipment, Integrated Management Systems: Quality - Environment - Safety - Technology: Proceedings of the International Conference, Gdańsk, Polska, Warszawa: STE Group Sp. z o. o. - New Trends in Production Engineering, Vol. 1 iss. 1, pp. 55-61, ISBN 978-83-952420-0-7; DOI: 10.2478/ntpe-2018-0007. 